\title{
Availability of Fodder Trees and Shrubs Integrated Into Agricultural Systems in Eastern Hararghe, Ethiopia
}

\author{
Dargo Kebede Alemie ${ }^{1} \&$ Haftay Hailu Gebremedhin ${ }^{2}$ \\ ${ }^{1}$ School of Natural Resource Management and Environmental Sciences, Haramaya University, Dire Dawa, \\ Ethiopia \\ ${ }^{2}$ School of Animal and Range Sciences, Haramaya University, Daire Dawa, Ethiopia \\ Correspondence: Dargo Kebede Alemie, School of Natural Resource Management and Environmental Scicences, \\ Haramaya University, P.O. Box 138, Dire Dawa, Ethiopia. E-mail: dargokebede@gmail.com
}

Received: July 25, 2018 Accepted: January 17, $2019 \quad$ Online Published: April 15, 2019

doi:10.5539/jas.v11n5p506 URL: https://doi.org/10.5539/jas.v11n5p506

The research is finanaced by Haramaya University Research and Extention office.

\begin{abstract}
Tree/shrub based feed resources and feeding systems in Eastern Hararghe are not studied well. Therefore, a study aimed at assessing the availability of fodder trees and shrubs integrated into farming system, available feed resources, and feeding systems was made in two districts of eastern Hararghe zone, Ethiopia. A total of 268 respondents from the two districts, both from lowland and highland agro ecology, were interviewed. Sørensen's Similarity Index was used to assess species composition in relation to agroecology. The result revealed that about $67.2 \%$ of the respondents have not integrated any fodder trees and shrubs into their farmlands whereas only $32.8 \%$ of the respondents integrated fodder trees and shrubs into their farmlands. A total of 20 fodder and non-fodder tree species were identified. Regarding tree species composition, only $46 \%$ of tree species were found in both districts, whereas about $54 \%$ of the tree species were dissimilar between the districts. The feeding system significantly varied with agroecology. Zero grazing system with stall-feeding technique is common in the highland agroecology. However, in the lowland agroecology free grazing on communal grazing area and feeding crop residue are common. Factors like inadequate extension service, lack of planting material and land scarcity has resulted in reduction of farmers' interest to integrate fodder trees and shrubs into their farming system.
\end{abstract}

Keywords: eastern Hararghe, fodder trees and shrubs, feeding systems, species composition

\section{Introduction}

In Ethiopia, about $85 \%$ of the total population directly depend on agriculture and live inrural areas (Krause et al., 2007). The livestock sub-sector plays an important role in the Ethiopian economy. Livestock contributes to the livelihoods of $60-70 \%$ of the population, and beside this, the sector serves as source of food, income and employment, manure, and also the subsector serves as productive assets that allow households to be self reliant (Zinash \& Tegegne, 2000; Ayele et al., 2002). Despite having good number of livestock, per unit productivity in Ethiopia is quite low (Shenkute et al., 2012). The current low productivity status of livestock in Ethiopia is caused by lack of forage. As grazing land becomes scarce due to expansion of agricultural land attributed to population growth and related factors, it aggravates the poor nutrition of livestock. In order to improve the productive and reproductive capacity of smallholder ruminant animals, there is a need to look at ways of extending the availability and quality of feedstuffs produced on smallholder farms. One potential way for increasing the quality and availability of feeds for smallholder ruminant animals in the dry season may be through the use of fodder trees and shrub. Fodder trees and shrubs have always played a role in feeding livestock (Azim et al., 2011). In Ethiopia, trees and shrubs have long been considered as source of feed for livestock in different parts of the country. Fodder trees and shrubs are an effective insurance against seasonal feed shortages or risk of drought, and hence vulnerability of farmers' livelihood to climate changes. They provide green feed when grasses and other herbaceous materials are dry and they provide the only source of energy and protein during drought when all other feed is absent (Lefroy et al., 1992). Trees and shrubs are important components of animal feeding and suppliers of protein especially in harsh environmental conditions when grazing is not 
sufficient to meet the maintenance requirements of animals, at least for part of the year (Speedy \& Pugliese, 1992).

Eastern Hararghe zone of Oromia National Regional State of Ethiopia is known for its cash crop production such as khat (Catha edulis), and others such as coffee, Irish potatoes and onions produced in the highland areas and to some extend groundnuts grown in the southern lowlands of East Hararghe Zone (Yves, 2000). Because khat is a highly valued cash crop and has a certain drought tolerance, Hararghe farmers increased and intensified khat production and started to grow it even in the lowlands. In addition to these, the area is characterized by high population pressure and its consequence of limited and rapidly diminishing land for food and forage production. This has resulted in scarcity of animal feed. Even if attempts have been made to introduce and disseminate forage grass species, still farmers are facing shortage of animal feed. Some alternative feed resources that fit the existing farming system and adapted to the economic realities of the farmers are needed. However, research on the availability of fodder trees and shrubs integrated into agricultural system have not been conducted yet. Thus, this study was carried out to assess the availability of fodder trees and shrubs integrated into farming system; and to identify available feed resources and feeding system.

\section{Methodology}

\subsection{Study Area Description}

The study was conducted at Babile $\left(09^{\circ} 13^{\prime} \mathrm{N} 42^{\circ} 20^{\prime} \mathrm{E}\right)$ and Kersa $\left(07^{\circ} 32^{\prime} \mathrm{N} 38^{\circ} 59^{\prime}\right.$ E) districts of Eastern Hararghe Zone, Ethiopia (Figure 1).

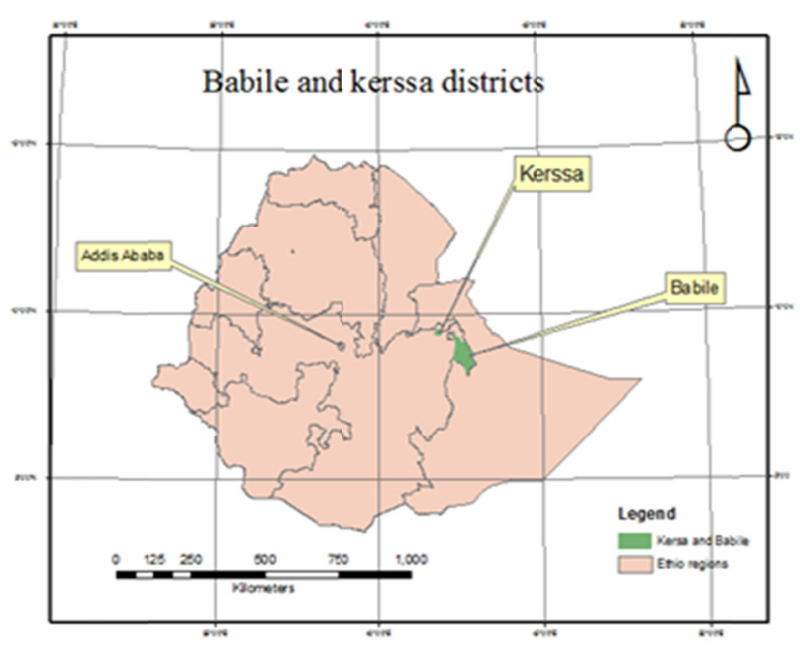

Figure 1. Map of the study districts

The altitude of Babile district ranges from 950 to 2000 meters above sea level. The survey was conducted at an elevation of about 1400 maters above sea level. The area receives an annual average rainfall of $569 \mathrm{~mm}$ with erratic distribution. The rainy seasons are from May to October with mean maximum and minimum temperature of 27.2 and $14.8{ }^{\circ} \mathrm{C}$, respectively. The soil of the study site is sandy loam in texture. The altitude of Kerssa district ranges from 1400 to 3200 meters above sea level. The survey was conducted at an elevation of about 2100 metres above sea level. The area receives an annual average rainfall of $750 \mathrm{~mm}$ with erratic distribution. The rainy seasons are from May to October with mean maximum and minimum temperature of 27.2 and $14.8^{\circ} \mathrm{C}$, respectively. The soil of the study site is sandy loam in texture.

The production system in the studied areas is a mixed crop livestock production system where farmers grow crops and keep livestock. The dominant crops that are grown vary with agroecology. In Kerssa district cereal crops such as sorghum, maize, wheat, barley and beans are cultivated. Sorghum and maize are given priority mainly targeting animal feed for their high biomass as animal feed. Khat, sweat potato and vegetables are also grown. Khat is the main cash crop followed by vegetables and sweat potato. In Babile District oil crop such as groundnut followed cereal crops such as sorghum and maize are given priority. Oil crop is the main cash crop followed by mango fruit.The type of livestock keep by farmers both in the highland and lowland agroecology are cattle, goat, donkeys and hen. Camels are kept only in the lowland ecology (Babile). 


\subsection{Sampling Procedure and Data Collection Method}

The intention to conduct the survey at these districts was to find out the availability of fodder trees and shrubs integrated in to the farming systems at two districts which have different agroecological characteristics i.e. Babile falls in the lowland agroecology while Kersa represents mid and highland agroecology.

A multi stage sampling technique was applied to select sample households. In the first stage, one district from high land and one district from lowland areas was selected purposively that can represent the familiarity of the districts for integration/managing of fodder trees in their farmland. In the second stage, one peasant association (PA) was selected from each district. In the third stage, households' were selected using simple random sampling techniques. The number of respondents was determined based on the sample size formula developed by Yamane (1967) as follows,

$$
\mathrm{n}=\frac{\mathrm{N}}{1+\mathrm{N}(\mathrm{e})^{2}}
$$

where, $\mathrm{n}=$ is the sample size for the research use (134); $\mathrm{N}$ is the population size (total number of households which is 202 from each PA); and e is the level of precision (0.05). A total of 268 respondents with 134 household heads each from Kerssa and Babile districts, respectively, were randomly selected and interviewed independently.

Data were collected from sample respondents, personal observations of physical features, and informal discussions with Development Agents (DAs). Both structured and semi- structured questionnaire was prepared for individual households.Before conducting the survey, the questionnaire was pre-tested by interviewing some households from other sites having similar agroecologies to that of the study areas. The necessary adjustment to the questionnaires was then made before fully duplicating and distributing to the enumerators. Regular monitoring was made by the researchers while enumerators were interviewing the respondents and daily evaluation of the filled questionnaires was undertaken throughout the data collection processes. The major contents of the questionnaire focused on the issues: the availability of fodder trees and shrubs integrated into agricultural system, factors affecting integration of fodder trees, feed resources and feeding systems.

Tree inventory was carried out to record all woody species found in the traditional agroforestry practices. The sample households that were selected for household survey were employed as a sample plot for inventory. Farmers were asked about name of the trees inlocal language (Oromifa) and the use of the plant species. Identification of species was done in the field. Nomenclature of the plant species followed the Flora of Ethiopia (Hedberg \& Edwards, 1995).

\subsection{Data Analysis}

To analyze the quantitative and qualitative data, statistical package for social sciences (SPSS 16 version) was used. Descriptive statistical methods such as frequency, percentage, mean, and standard deviation were used. For categorical variables, a chi-square test was used to test the difference between the agroecologiesat the significance level (0.05). The trees species composition between the different agroecologies was computed using the Sørensen's Similarity Index: $I_{S}=2 c / a+b+2 c$, where, $I_{S}$ is Sørensen's Similarity Index; a representing the number of species unique to sample $\mathrm{a}$; $\mathrm{b}$ representing the number of species unique to sample $\mathrm{b}$; and $\mathrm{c}$ representing the number of species in common.

\section{Results and Discussion}

\subsection{Socio-economic Characteristics of the Respondents}

Interviewed respondents comprised $75.4 \%$ male and $24.6 \%$ female with age ranging from 20 to 72 years and an average age of $36.05 \pm 11.8$ years. The average family size of the respondents was $6.01 \pm 2.45$; and the average land holding size was $1.34 \pm 1.08$ ha (Table 1). 
Table 1. The socio-economic profile of sampled household $(n=268)$ in Kersa and Babile districts, eastern Ethiopia

\begin{tabular}{lllll}
\hline Variable definition & Categories & Kerssa district (\%) & Babile district (\%) & $\mathrm{X}^{2}$-Test \\
\hline \multirow{2}{*}{ Sex } & Male & 73.88 & 82.1 \\
& Female & 26.12 & 17.91 & 17.91 \\
& $0-0.5$ & 41.04 & 21.64 & $0.01 * * *$ \\
Agricultural land holding size (ha)/household & $0.5-1$ & 37.31 & 44.78 \\
& $1-1.5$ & 14.93 & 12.69 \\
\hline Age mean + Std. Deviation & $1.5-2$ & 6.72 & 2.98 & 0.06 \\
Family size mean + Std. Deviation & & 0 & $36.6+11.8$ & $6.5+1.5$ \\
\hline
\end{tabular}

Note. ${ }^{* * *}$ superscript indicates significant difference between studied parameters of respondents.

\subsection{Availability of Fodder Trees and Shrubs Integrated Into Farmlands}

The result of the respondent's response for integration fodder trees and shrubs into their farmlands were not varied with agroecology $\left(\mathrm{X}^{2}=1.63 ; \mathrm{df}=1 ; \mathrm{p}=0.21\right.$ ) (Table 2). The result of household survey revealed that, about $67.2 \%$ of the respondents have not integrated any fodder trees and shrubs into their farmlands whereas only $32.8 \%$ of the respondents integrated fodder trees and shrubs into their farmlands.

In general, a total of twenty tree and shrub species were identified in the study area out of which seven species were primarily promoted for construction material, nine for fodder and four for fruit (Table 2).

Table 2. Frequency of tree species identified in Kerssa and Babile districts, eastern Ethiopia

\begin{tabular}{lll|lll}
\hline Species name & Kerssa & Babile & Species name & Kerssa & Babile \\
\hline Construction material & & & Carissa edulis & $*$ & $*$ \\
Cordia africana & $*$ & $*$ & Gardena ternifolia & - & $\mathrm{X}$ \\
Casuerina cunninghamiana & $*$ & $*$ & Grewia bicolour & - & $\mathrm{X}$ \\
Croton macrostachyus & $\mathrm{X}$ & - & Ricinus communis & $\mathrm{X}$ & - \\
Eshretia cymosa & - & $\mathrm{X}$ & Sesbania sesben & $\mathrm{X}$ & - \\
Eucalyptus robusta & $*$ & $*$ & Terminalia brownie & - & $\mathrm{X}$ \\
Juniperus procera & $\mathrm{X}$ & - & Ziziphusspina-christi & - & $\mathrm{X}$ \\
Olea europaea & $\mathrm{X}$ & - & Fruit & & - \\
Fodder & & & Annona senegalensis & $\mathrm{X}$ & - \\
Acacia sieberiana & $\mathrm{X}$ & - & Casimiroa edulis & $\mathrm{X}$ & $*$ \\
Acacia brevispica & - & $\mathrm{X}$ & Mangifera indica & $*$ & $*$ \\
Carissa edulis & $*$ & $*$ & Psidium guajava & $*$ & $*$ \\
\hline
\end{tabular}

Note. ${ }^{*}=$ common species in Kerssa and Babile districts; $\mathrm{X}=$ species found at one district only.

Fodder or browse production from trees is one of the benefits of agroforestry. Fodder trees and shrubs become then important as a source of energy and protein to keep the animals' body healthy, improve growth rates and even increase milk and wool production (Azim et al., 2011). Hence, it is clear that farmer's involvement in establishment of fodder trees and shrubs in the development of new agroforestry technologies is important, right from the beginning.

However, in the study area most of the farmers (i.e., about $67.2 \%$ of the respondents) have not integrated any fodder trees and shrubs into their farmlands. Roothaert, (2000) noted that farmer's decisions to allow trees to grow on the farm are influenced by such importance or personal preferences. In the study area factors such as inadequate extension services, lack of planting material and land scarcity respectively (Figure 2) are the reasons that were identified by the respondents for not integrating fodder trees and shrubs into their farmlands. Although farmers seem to have a clear idea of the feeding value of fodder trees, and interested to grow them on-farm, 
ignoring these farmers' factors may result in reduction of farmer's adoption of agroforestry practice for fodder production.

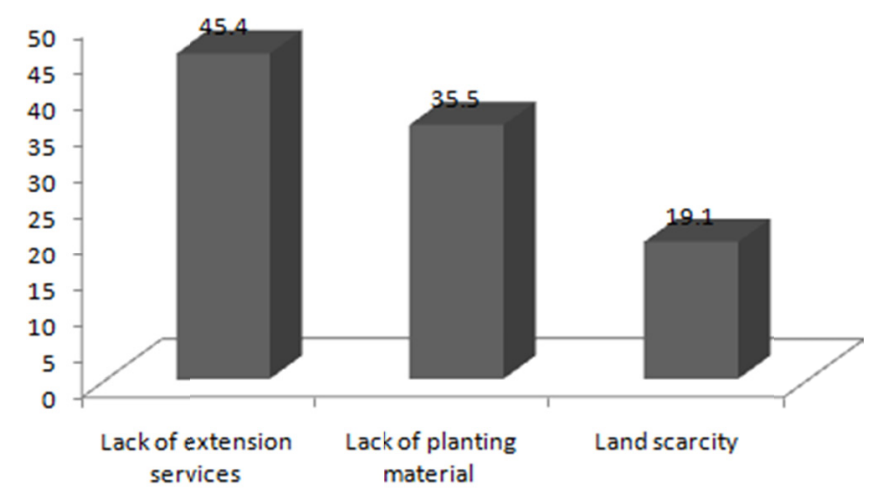

Figure 2. Farmers' response for the factors not to integrated fodder trees and shrubs into agricultural system in Easten Hararghe, Ethiopia

However, few numbers of respondents (32.8\%) integrated different trees species as dry season fodder source. While, about $79.1 \%$ of the respondents have maintained different types of tree species on their farmland. As stated by Franzel and Scherr (2002) agro-forestry is a dynamic ecologically based natural resource management system that through the integration of tree/woody perennials into farm and rangelands diversifies and sustains production for increased social, economic and environmental benefits. Thus, fodder agroforestry systems can be designed to deliver additional benefits such as soil and water conservation, timber and fuel wood. Yet, most of the farmers in the study area owned few trees species for the use of construction material. Mainly, Eucalyptus robusta is the most dominant and preferred tree species that was maintained by farmers followed by Cordia africanain at both districts. Farmers in the study area choice Eucalyptus robusta as most preferred for construction material because of its fast growing habit and farmers have got a secured market for the species.

Farmers can plant trees/shrub species on the edge of their farm or integrate with food/cash crops. Homestead, farm boundary, live fence, grazing land and farm land were the niches where treeswere planted and maintained in the study areas. Among the aforementioned niches, homestead was the most preferred niche by the majority of the respondents followed by farm boundary and farmland (Figure 2).

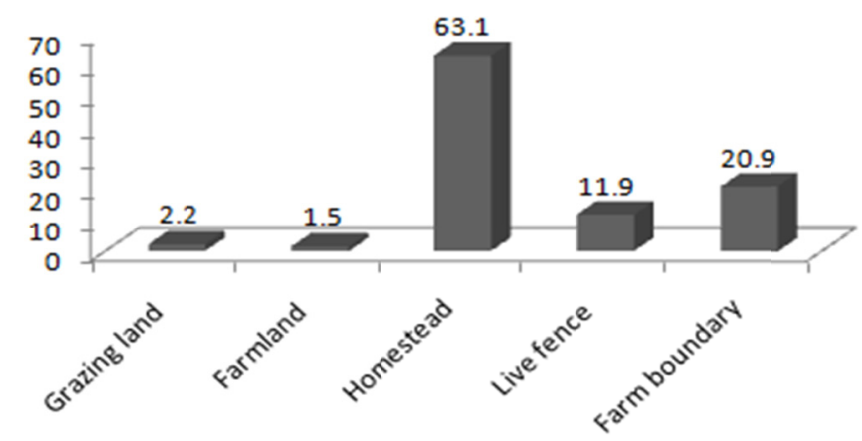

Figure 3. Response of respondent for niches of different tree species in Eastern Hararghe, Ethiopia

\subsection{Tree Species Composition}

Sørensen's Similarity Index was used to assess species composition variation between the different agroecologies. The tree species composition showed clear pattern of distributions in relation to the agroecologies. Sørensen's Similarity Index between the districts indicated that only $46 \%$ of the tree and shrub species were found common in both districts, whereas about $54 \%$ tree species were dissimilar between the districts.

Not all types of fodder trees and shrubs perform well in each area. Different types of trees and shrubs are suited to different altitudes, climates (depending on temperature and amount of rainfall) and soil types (André van, 2004). In 
the study area among the identified species as fodder trees only Carissa edulis was found in common in both districts. Species used as dry season fodder like Acacia sieberiana, Ricinus communis and Sesbania sesban were identified only in Kerssa district.While, Acacia brevispica, Gardena ternifolia, Grewia bicolour, Terminalia brownie and Ziziphusspina-christiwere found only in Babile district. Most of the identified fodder trees in the present study area were indigenous species, which are most suited to the local climatic and edaphic condition of the area. However, exotic species like Sesbania sesban also identified in the highland agroecology conditions. Sesbania sesban is an important multipurpose fodder shrub exotic to Ethiopia and is originally from east Africa (Mekoya, 2008).

Some of the fodder species identified in the study area (Table 2) are similar to those described by many authors in Ethiopia (Shenkute et al., 2012; Beyene, 2009; Teferi, 2006; Abule, 2003). Shenkute et al. (2012) documented Acacia tortilis, Ficus gnaphalocarpa, Balanites aegyptica, Dichrostachys cinerea and Grewiabicolour as most widely utilized browse species in Mid Rift Valley of Ethiopia. Beyene (2009) in his study in south western Ethiopia indicated Rhusna talensis, Grewia ferruginea, Bauhinia farea, Deinbolliakilimandscharicaand Acacia seyal as the common browse in the Gembella National Regional State, Ethiopia. Acacia species andGrewia mollis were also reported as the most commonly utilized species in the Rift Valley of Ethiopia (Abule, 2003). Teferi (2006) also documented Ziziphus spina-christi, Acacia asak, Acacia lahai, Balanites aegyptiaca andTerminalia brownie as some of the most distributed browses species in northern Ethiopia.

\subsection{Feed Resource and Feeding Systems}

Grass and crop residues are the main sources of feed in both districts. However, the feeding system are significantly different with agroecology in the study area $\left(X^{2}=98.8 ; d f=2 ; p=000\right)$. In Kerssa district the main feeding system is stall-feeding. The major feed resources are sorghum and maize stover, straw, maize and sorghum leaves, thinned maize and sorghum seedlings and sterile plants, sweet potato leaves, haricot bean leaves and weeds grown in crop fields. Cattle, sheep and goats were observed tied with rope near crop fields or Khat fields. However, in Babile district livestock feeding is based on free grazing on communal grazing lands, road sides and crop residue (maize and sorghum stover, groundnut leaf and stem). The most common form of management in the area is mixture of grazing (communal land, crop land) and stall-feeding. Particularly in the khat based agroforestry system of Kerssa district, zero grazing system with stall-feeding technique is the most common practice. This agrees withthe idea that grazing land in eastern Hararghe is very little and usually fewer animals are found (Gebregziabher \& Gebrehiwot, 2011). More intensive utilization of tree forages and shrubs is dependent on the type of feeding systems practiced.

Table 3. Farmers' response on integration of fodder trees and shrubs and feeding systems in two districts in eastern Hararghe, Ethiopia

\begin{tabular}{|c|c|c|c|c|c|}
\hline Variable definition & Categories & Kerssa district (\%) & Babile district $(\%)$ & Total $(\%)$ & $\mathrm{X}^{2}$-Test \\
\hline \multirow{2}{*}{$\begin{array}{l}\text { Fodder trees and shrubs } \\
\text { integrated into farmland }\end{array}$} & $0=$ no & 61.5 & 72.5 & 67.2 & \multirow{2}{*}{0.06} \\
\hline & $1=$ yes & 38.5 & 27.5 & 32.8 & \\
\hline \multirow{2}{*}{ Tradition of tree inclusion on farmlands } & $0=$ no & 16.9 & 23.2 & 20.1 & \multirow{2}{*}{0.21} \\
\hline & $1=$ yes & 63.1 & 76.8 & 79.9 & \\
\hline \multirow{3}{*}{ Feeding system } & Stall feeding & 50.8 & 5.1 & 27.2 & \multirow{3}{*}{$0.000 * * *$} \\
\hline & Stall feeding + free grazing & 36.2 & 29.0 & 3.5 & \\
\hline & Free grazing & 13.1 & 65.9 & 40.7 & \\
\hline
\end{tabular}

Note. ${ }^{* * *}$ superscript indicates significant difference between studied parameters of respondents.

But an important problem diagnosed in the study area specifically at Kerssa is lack of fodder during the dry season (Figure 3). 


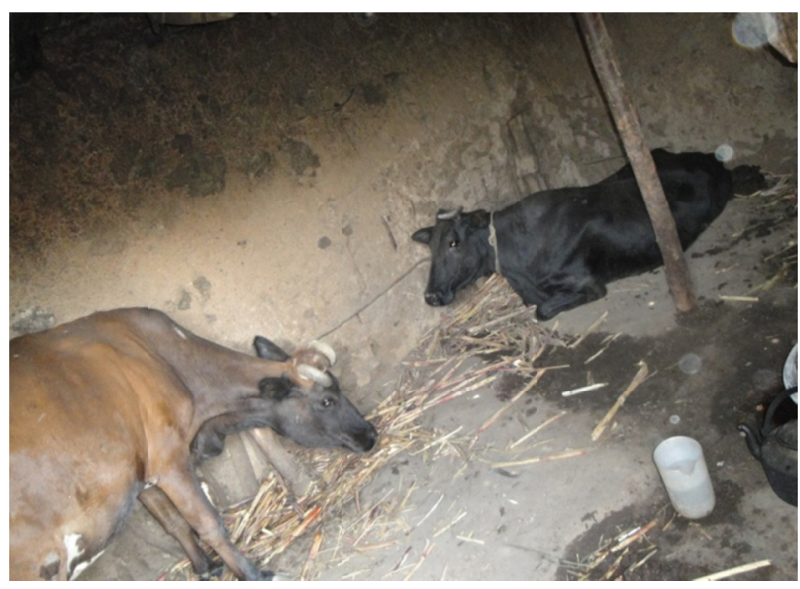

Figure 3. Cattle feeding crop residue (sorghum stalk and dried maize leaf) during the dry season in Kerssa district, eastern Hararghe, Ethiopia

As indicated in the Table 1 farmers in Babile distrct have relatively large farm size (44.78\% of them have 1-1.5 ha of land per household and $12.69 \%$ of them have 1.5-2 ha of land) which allowed them to practice free grazing system. Where as, in Kersa distrct farmers have small piece of land ( $41.04 \%$ of the farmers own $0-0.5$ ha of land per household and $37.31 \%$ of the farmers own $0.5^{-1}$ ha of land). This has forced them to practice stall-feeding system.

Feed shortage is a critical problem in the study areas, mainly during the dry season (March to June) when farmers finish stored feed (Gebregziabher \& Gebrehiwot, 2011). As depited in the above picture (Figure 3) the existing feed resources in the study area, grass and crop residues are poor in quality and provide insufficient protein, energy, vitamins and minerals (Preston, 1995). Such low quality feeds are associated with a low voluntary intake, thus resulting in insufficient nutrient supply, low productivity and even weight loss (Hindrichsen et al., 2004). In view of the potentially high nutritive value of tree foliage, it was reasoned that deep rooted, woody plants could help to over come these problem if fed as a supplement to the basal diet (Kabirizi et al., 2006). A number of authors (Alemu et al., 1991; Oosting, 1993; Tsige, 2000) also proposed means to achieve better utilization of fibrous feeds include the cultivation and use of leguminous forage crops (herbaceous legumes and fodder trees and shrubs). Demonstration programes should also be arranged by both governmental and non govermnetal organizations to create awarness to farmers on how to grow, integrate, manage and utlize fodder trees and shrubs along with food crop production system.

Unlike most farmers in the study area, farmers in different region who have similar production systems showed a potential for integrating fodder trees in their farming systems. For example, the farmers in Central Kenyan highlands have experiencedthe habit of planting fodder trees as a fodder bank around the compound or near the zero grazing units (Thijssen et al., 1993). Fagg and Stewart (1994) also noted that browse species have considerable potential for mixed crop livestock production system to overcome low nutritive value of crop residues and mature native pasture that limit livestock productivity in sub-Saharan Africa. Study conducted in Kenya by Vander Veen (1993) indicated that browse species can be successfully used in feeding milking animals. Generally, the importance of fodder trees and shrubs become prominent in animal feeding towards the end of the dry season when crop residues are all used up and the quality and quantity of grass is at its worst.

\section{Conclusion}

This study indicated that although farmers have clear idea of the feeding value of fodder trees, and interested to grow on their farm, ignoring farmers' factors such as inadequate extension service, lack of planting material and land scarcity would result in reduction of farmers' interest to integrate fodder trees and shrubs into their agricultural system.Farmers also indicated that if adequate demonstration program is organized and aware them on the potential contribution of trees and shrubs as source of feed for livestock, their management technique and feeding systems, there is still a room to integrate fodder trees and shrubs in to their farming system. The other important point farmers rose as bottleneck is lack of planting material. This justifies the need to provide farmers sufficient planting materials (seed, seedlings or cuttings) and intensify the planting and utilization of fodder trees and shrubs in the available niche at the farmland. By doing so it is possible to increase the current level of the contribution of trees and shrubs as source of feed for livestock in the study areas. However, the species described 
as fodder by few farmers need further investigation in terms of chemical and tannin analysis, palatability and digestibility in order to enhance their utilization in the future.

\section{References}

Abule, E. (2003). Rangeland evaluation in relation to pastoralists' perceptions in the Middle Awash Valley of Ethiopia (p. 297, PhD thesis submitted to the University of the Free State, Bloemfontein, South Africa). Retrieved from http://scholar.ufs.ac.za:8080/xmlui/handle/11660/6302

Alemu, Y., Zinash, S., \& Seyoum, B. (1991). The potential of crop residues and agro-industrial by-products as animal feed. Proceedings of Third National Livestock Improvement Conference (pp. 57-64). IAR (Institute of Agricultural Research), Addis Ababa, Ethiopia.

André van, T. (2004). Fodder Trees. Retrieved October 15, 2013, from http://www.agromisa.org

Azim, A., Ghazanfar, S., Latif, A., \& Nadeem, M. A. (2011). Nutritional Evaluation of Some Top Fodder Tree Leaves and Shrubs of District Chakwal, Pakistan in Relation to Ruminants Requirements. Pakistan Journal of Nutrition, 10(1), 54-59. https://doi.org/10.3923/pjn.2011.54.59

Bayer, W. (1990). Use of browse by Fulani cattle in Central Nigeria. Agroforestry Systems, 12(3), $217-228$. https://doi.org/10.1007/BF00137285

Beyene, T. (2009). Assessment of livestock feed resources, feeding systems and rangeland condition in Assosa Zone, Benishangul-Gumuz Region (M.Sc. thesis, Hawassa University, Hawassa, Ethiopia).

Fagg, C. W., \& Stewart, J. L. (1994). The value of Acacia and Prosopis in Arid and Semi-Arid environments. Journal of Arid Environments, 27(1), 3-25. https://doi.org/10.1006/jare.1994.1041

Frenzel, S., \& Scherr, S. J. (2002). Trees on farm. Assessing the adoption potential of agroforestry practices in Africa (pp. 1-9). CABI Publishing, ICRAF, Nairobi, Kenya. https://doi.org/10.1079/9780851995618.0000

Gebregziabher, G., \& Gebrehiwot, H. (2011). Challenges, Opportunities and Available Good Practices related to Zero Grazing in Tigray and Hararghe, Ethiopia. Dry Land Coordination Group (DCG) Report No. 66.

Hedberg, I., \& Edwards, S. (1995). Flora of Ethiopia (Vol. 3). The National Herbarium: Addis Ababa, Ethiopia.

Hindrichsen, I. K., Osuji, P. O., Odenyo, A. A., Madsen, J., \& Hvelplund, T. (2004). Effect of supplementation of maize stover with foliage of various tropical multipurpose trees and Lablab purpureus on intake, rumen fermentation, digest kinetics and microbial protein supply of sheep. Animal Feed Science and Technology, 113, 83-96. https://doi.org/10.1016/j.anifeedsci.2003.10.017

Kabirizi, J., Mpairweand, D., \& Mutetikka, D. (2006). Effect of intercropping forage legumes with elephant grass on fodder production in intensive smallholder dairy farms in Uganda. Uganda Journal of Agricultural Sciences, 12(2), 16-25.

Krause, M., Uibrig, H., \& Kidane, B. (2007). Decision Modelling for the Integration of Woody Plants in Smallholder Farms in the Central Highlands of Ethiopia. Journal of Agriculture and Rural Development in the Tropics and Subtropics, 108(1), 1-17.

Lefroy, E. C., Dann, P. R., Wildin, J. H., Wesley-Smith, R. N., \& Mcgowan, A. A. (1992). Trees and shrubs as sources of fodder in Australia. Agroforestry Systems, 20, 117-139. https://doi.org/10.1007/BF00055307

Mekoya, A. K. (2008). Multipurpose fodder trees in Ethiopia; Farmers'perception, constraints to adoption and effects of long-term supplementation on sheep performance ( $\mathrm{PhD}$ thesis, Wageningen University, Wageningen, the Netherlands).

Oosting, S. J. (1993). Wheat straw as ruminant feed: Effect of supplementation and ammonia treatment on voluntary intake and nutrient availability $(\mathrm{PhD}$ Thesis, Wageningen University, Wageningen, The Netherlands).

Preston, T. R. (1995). Tropical animal feeding (p. 305). A manual for research workers. FAO (Food and Agriculture Organization) Animal production and Health paper 126. FAO, Rome, Italy.

Roothaert, R. L. (2000). The potential of indigenous and naturalized fodder trees and shrubs for intensive use in central Kenya (PhD thesis, Wageningen University the Netherlands).

Shenkute, B., Hassen, A., Assafa, T., Amen, N., \& Ebro, A. (2012). Identification and nutritive value of potential fodder trees and shrubs in the Mid Rift Valley of Ethiopia. The Journal of Animal \& Plant Sciences, 22(4), 1126-1132. 
Speedy, A., \& Pugliese, P. (1992). Legume trees and other fodder trees as protein sourcesfor livestock. FAO Animal Production and Health Paper 102 (P5). Proceedings of the FAO Expert Consultation held at the Malaysian Agricultural Research and Development Institute (MARDI) in Kuala Lumpur, Malaysia.

Teferi, A. (2006). Identification and nutritional characterization of major browse species in Abergelle Woreda of Tigray, Ethiopia (M.Sc. thesis, Alemaya University, Alemaya, Ethiopia).

Thijssen, H. J. C., Murithi, F. M., \& Nyaata, O. Z. (1993). Existing Hedges on Farms in the Coffee Based Land Use System of Embu District, Kenya (AFRENA Report No. 65). ICRAF, Nairobi.

Tsige, Y. H. (2000). Livestock feed security and associated impacts on sustainable agricultural development (pp. 51-61). Proceedings of the 7th Annual Conference of Ethiopian Society of Animal Production (ESAP), Addis Ababa, Ethiopia.

Van der Veen, W. (1993). Economic analysis of fodder trees for dairy cows on farms in western Kenya (PhD thesis, Wageningen Agricultural University, The Netherlands).

Yves, G. (2000). Hararghe Agro-pastoralists Face an Uncertain Future. Focus on livelihoodin selected belgdependant areas of East and West Hararghe. UN-Emergencies Unit for Ethiopia.

Zinash, S., \& Tegegne, A. (2000). Challenges and opportunities for livestock development in the highlands of Ethiopia. In P. M. Tulachan, M. A. Mohamed-Saleem, J. Maki-Hokkonen \& J. Partap (Eds.), Contribution of livestock to mountain livelihoods: Research and development Issues. Proceedings of the International symposium on livestock in mountain/highland production systems: Research and development challenges into the next millennium (pp. 95-102). Pokhara, Nepal.

\section{Copyrights}

Copyright for this article is retained by the author(s), with first publication rights granted to the journal.

This is an open-access article distributed under the terms and conditions of the Creative Commons Attribution license (http://creativecommons.org/licenses/by/4.0/). 